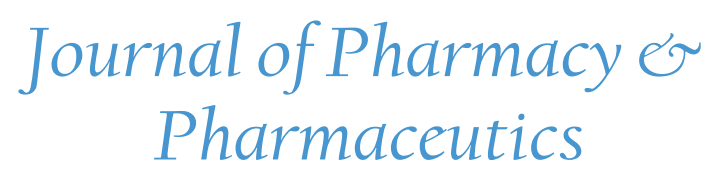

OMMEgA Publishers

Answering Intelligence

\title{
Transport Therapeutic Active Targeting of Human Brain Tumors Enable Anti-Cancer Nanodrugs Delivery across the Blood-Brain Barrier (BBB) to Treat Brain Diseases Using Nanoparticles and Nanocarriers under Synchrotron Radiation
}

\author{
Alireza Heidari* \\ Faculty of Chemistry, California South University, 14731 Comet St. Irvine, USA
}

"Corresponding author: Alireza Heidari, Faculty of Chemistry, California South University, 14731 Comet St. Irvine, CA 92604, USA, E-mail: Scholar.Researcher.Scientist@gmail.com

Citation: Alireza Heidari, Transport Therapeutic Active Targeting of Human Brain Tumors Enable Anti-Cancer Nanodrugs Delivery across the Blood-Brain Barrier (BBB) to Treat Brain Diseases Using Nanoparticles and Nanocarriers under Synchrotron Radiation. (2017) J Pharm Pharmaceutics 4(2): 151- 155.

DOI: $10.15436 / 2377-1313.17 .034$
Received date: June 30, 2017

Accepted date: September 18, 2017

Published date: September 22, 2017

\section{Short Communication}

The separation of impurities nano-molecules such as anti-cancer nanodrug molecules, from waste waters is important in nano-medicinal and pharmaceutical industries and human life. Mesoporous molecular sieves, like Al- and Ti-MCM-41 (Mobil Composition of Matter No. 41) materials, offer substantial promise as separations media due to their properties such as a highly regular structure, uniform pore sizes and high surface areas. In this short communication, we want to transport therapeutic active targeting of human brain tumors enable anti-cancer nanodrugs delivery across the Blood-Brain Barrier (BBB) to treat brain diseases using nanoparticles and nanocarriers under synchrotron radiation. For example, Pseudoephedrine hydrochloride $\left(\mathrm{C}_{10} \mathrm{H}_{15} \mathrm{ON}, \mathrm{HCl}\right)$ which is water soluble anti-cancer nanodrug compounds. It widely used as narcotic and highly toxic when it contact with skin and eye, causes various types of allergies- from waste waters with mesoporous materials such as Al- and Ti-MCM-41 (Mobil Composition of Matter No. 41) materials. The revolution of surface characteristic and pore structure of Al- and Ti-MCM-41 (Mobil Composition of Matter No. 41) materials induced by anti-cancer nanodrugs adsorption were characterized based on the analyses of the Nitrogen isotherms, the X-Ray Diffraction (XRD) patterns and ${ }^{1} \mathrm{HNMR}$, ${ }^{13} \mathrm{CNMR},{ }^{31} \mathrm{PNMR}$, Attenuated Total Reflectance Fourier Trans- form Infrared (ATR-FTIR), FT-Raman, UV-Vis and HR Mass spectra. The adsorption of anti-cancer nanodrugs on $\mathrm{Al}-$ and Ti-MCM-41 (Mobil Composition of Matter No. 41) materials with respect to contact time, $\mathrm{pH}$ and temperature was then measured to provide more information about the adsorption characteristic of Al- and Ti-MCM-41 (Mobil Composition of Matter No. 41) materials. In this short communication, reports on the synthesis and photo catalytic evaluation of mesoporous sized titania supported Al-and Ti-MCM-41 (Mobil Composition of Matter No. 41) materials by photo degrading Pseudoephedrine hydrochloride $\left(\mathrm{C}_{10} \mathrm{H}_{15} \mathrm{ON}, \mathrm{HCl}\right)$ in the presence of electron acceptors such as Peroxodisulphate (PDS) and $\mathrm{H}_{2} \mathrm{O}_{2}$ using UV and visible-light irradiation. This system is relatively inexpensive, reproducible, extremely stable and efficient in complete degradation of anti-cancer nanodrugs in aqueous solution. In order to obtain maximum information about the performance of Al- and Ti-MCM-41 (Mobil Composition of Matter No. 41) materials catalyst, we did experiments under different operating conditions, i.e., variation of amount of catalyst, concentration of Pseudoephedrine hydrochloride $\left(\mathrm{C}_{10} \mathrm{H}_{15} \mathrm{ON}, \mathrm{HCl}\right)$ and electron acceptors. In addition to the mentioned above, a comparative study on the photo catalytic activities of colloidal $\mathrm{TiO}_{2}$ was also made to transport therapeutic active targeting of human brain 
tumors enable anti-cancer nanodrugs delivery across the BloodBrain Barrier (BBB) to treat brain diseases using nanoparticles and nanocarriers under synchrotron radiation.

Paracetamol (N-acetyl-p-aminophenol, acetaminophen (ACT)) is a long-established and one of the most extensively employed "over the counter" anti-cancer nanodrugs in the world. It was first used in medicine by Von Mering in 1983. It is non-carcinogenic and an effective substitute to aspirin for patients with sensitivity to aspirin. Acetaminophen (ACT) blocks pain messages to the brain by stopping a chemical called prostaglandin, which causes pain and fever. Numerous methods have been used for the determination of paracetamol in pharmaceutical formulations, nanomedicinal and biological fluids including titrimetry, UV-Vis spectrophotometry, spectrofluorimetry, ${ }^{1} \mathrm{HNMR},{ }^{13} \mathrm{CNMR},{ }^{31} \mathrm{PNMR}$, Attenuated Total Reflectance Fourier Transform Infrared (ATR-FTIR), FT-Raman, UV-Vis and HR Mass spectroscopies, electrochemical methods and chromatography. The present short communication describes a rapid and accurate amperometric technique for the determination of acetaminophen (ACT) in nanomedicinal and pharmaceutical preparations and human blood serum, based on electro catalytic oxidation of acetaminophen (ACT) at a glassy Carbon electrode modified by Cadmium pentacyanonitrosylferrare $(\mathrm{Cd}$ PCNF) film. The electro catalytic response of the modified Gas Chromatography (GC) electrode was linear over the concentration range $2.27-63.23 \mu \mathrm{M}$. The LOD was found to be $4.84 \mu \mathrm{M}$. The method was successfully utilized for the determination of acetaminophen (ACT) in various nanomedicinal, pharmaceutical and biological preparations and the results have been statistically compared with those obtained by the official method. The interference of some nanomedicinal, pharmaceutical and biological nanocompounds was investigated. The results showed that the Nafion-coated CdPCNF/GC electrode can be utilized as a selective amperometric sensor for acetaminophen (ACT) determination in human blood serum. Also, the mean value of rate constant $k$ for catalytic reaction and the diffusion coefficient of acetaminophen $(\mathrm{ACT})(D)$ in the phosphate buffer solution of $\mathrm{pH} 7.5$ were found to be $5.81 \times 10^{2} \mathrm{M}^{-1} \mathrm{~s}^{-1}$ and $(5.45 \pm 0.75) \times$ $10^{-6} \mathrm{~cm}^{2} \mathrm{~s}^{-1}$, respectively.

Paclitaxel, camptothecin, doxorubicin, cisplatin and curcumin are most used anti-cancer nanodrugs, which are tested for nanomedicinal and pharmaceutical applications. The anticancer nanodrugs are mostly encapsulated into the liposomes or micelles or conjugated with Polyethylene Glycol (PEG) ${ }^{[1-73]}$. They transport therapeutic active targeting of human brain tumors enable anti-cancer nanodrugs delivery across the BloodBrain Barrier (BBB) to treat brain diseases using nanoparticles and nanocarriers under synchrotron radiation. Paclitaxel, camptothecin, doxorubicin, cisplatin and curcumin are able to transport therapeutic active targeting of human brain tumors enable anti-cancer nanodrugs delivery across the Blood-Brain Barrier (BBB) to treat brain diseases using nanoparticles and nanocarriers under synchrotron radiation. Previous methods for determining paclitaxel, camptothecin, doxorubicin, cisplatin and curcumin have included liquid chromatography, fluorimetry and spectroscopy. Compared to the other techniques, electro analytical methods have the advantages of simplicity, low expense and high sensitivity. In this short communication, we describe the use of ferrocenedicarboxylic acid as a mediator for the electro oxidation of paclitaxel, camptothecin, doxorubicin, cisplatin and curcumin in aqueous media. Also, cyclic voltammetry, differential pulse voltammetry and double potential step chronoamperometry were used to characterize the electrochemical properties of the paclitaxel, camptothecin, doxorubicin, cisplatin and curcumin to investigate its electro catalytic effect on the oxidation of paclitaxel, camptothecin, doxorubicin, cisplatin and curcumin to transport therapeutic active targeting of human brain tumors enable anti-cancer nanodrugs delivery across the Blood-Brain Barrier (BBB) to treat brain diseases using nanoparticles and nanocarriers under synchrotron radiation. The linear dynamic range of the sensors is $6 \times 10^{-7} \mathrm{M}-3.6 \times 10^{-4} \mathrm{M}$ with a limit of detection of $11.23 \times 10^{-8} \mathrm{M}$. The advantages of this modified electrode are good reproducibility, excellent catalytic activity, simplicity of preparation and especially its antifouling properties towards paclitaxel, camptothecin, doxorubicin, cisplatin and curcumin and their oxidation products to transport therapeutic active targeting of human brain tumors enable anti-cancer nanodrugs delivery across the Blood-Brain Barrier (BBB) to treat brain diseases using nanoparticles and nanocarriers under synchrotron radiation.

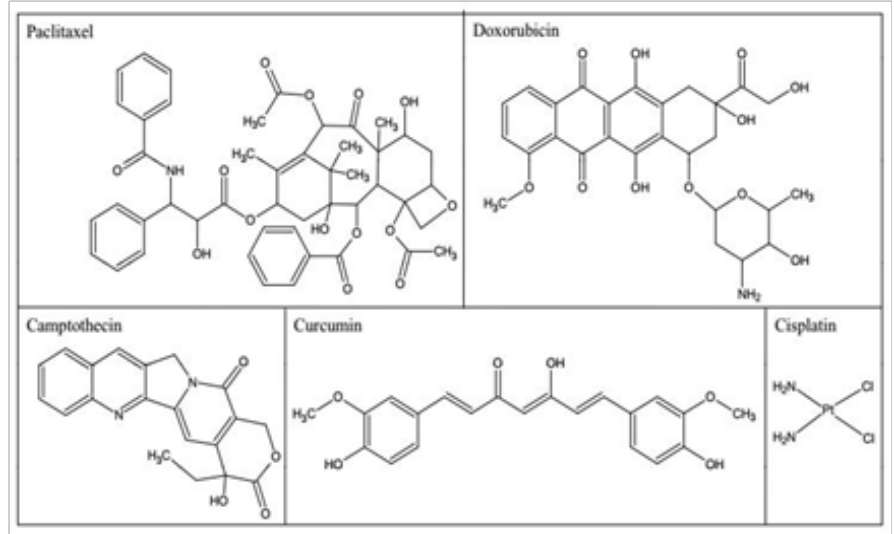

Figure 1: Molecular and chemical structures of several most used anticancer nanodrugs (paclitaxel, camptothecin, doxorubicin, cisplatin and curcumin), which are tested for nanomedicinal and pharmaceutical applications $^{[1-73]}$. 


\section{References}

1. Heidari, A., Brown, C. Study of Composition and Morphology of Cadmium Oxide (CdO) Nanoparticles for Eliminating Cancer Cells. (2015) J Nanomedicine Res 2(5): 20.

Pubmed | Crossref $\mid$ Others

2. Heidari, A., Brown, C. Study of Surface Morphological, Phytochemical and Structural Characteristics of Rhodium (III) Oxide $\left(\mathrm{Rh}_{2} \mathrm{O}_{3}\right)$ Nanoparticles. (2015) International J Pharmacol, Phytochem and Ethnomedicine 1: 15-19.

Pubmed | Crossref | Others

3. Heidari, A. An Experimental Biospectroscopic Study on Seminal Plasma in Determination of Semen Quality for Evaluation of Male Infertility. (2016) Int J Adv Technol 7: 007.

Pubmed | Crossref $\mid$ Others

4. Heidari, A. Extraction and Preconcentration of N-Tolyl-SulfonylPhosphoramid-Saeure-Dichlorid as an Anti-Cancer Drug from Plants: A Pharmacognosy Study. (2016) J Pharmacogn Nat Prod 2: 103.

Pubmed | Crossref | Others

5. Heidari, A. A Thermodynamic Study on Hydration and Dehydration of DNA and RNA-Amphiphile Complexes. (2016) J Bioeng Biomed Sci S: 006.

Pubmed | Crossref $\mid$ Others

6. Heidari, A. Computational Studies on Molecular Structures and Carbonyl and Ketene Group's Effects of Singlet and Triplet Energies of Azidoketene $\mathrm{O}=\mathrm{C}=\mathrm{CH}-\mathrm{NNN}$ and Isocyanatoketene $\mathrm{O}=\mathrm{C}=\mathrm{CH}-\mathrm{N}=\mathrm{C}=\mathrm{O}$. (2016) J Appl Computat Math 5: 142.

Pubmed | Crossref | Others

7. Heidari, A. Study of Irradiations to Enhance the Induces the Dissociation of Hydrogen Bonds between Peptide Chains and Transition from Helix Structure to Random Coil Structure Using ATR-FTIR, Raman and ${ }^{1}$ HNMR Spectroscopies. (2016) J Biomol Res Ther 5: 146.

Pubmed | Crossref | Others

8. Heidari, A. Future Prospects of Point Fluorescence Spectroscopy, Fluorescence Imaging and Fluorescence Endoscopy in Photodynamic Therapy (PDT) for Cancer Cells. (2016) J Bioanal Biomed 8: 135.

Pubmed $\mid$ Crossref $\mid$ Others

9. Heidari, A. Bio-Spectroscopic Study of DNA Density and Color Role as Determining Factor for Absorbed. Irradiation in Cancer Cells. (2016) Adv Cancer Prev 1: 102.

Pubmed | Crossref | Others

10. Heidari, A. Manufacturing Process of Solar Cells Using Cadmium Oxide (CdO) and Rhodium (III) Oxide $\left(\mathrm{Rh}_{2} \mathrm{O}_{3}\right)$ Nanoparticles. (2016) J

Biotechnol Biomater 6: 125.

Pubmed | Crossref | Others

11. Heidari, A. A Novel Experimental and Computational Approach to Photo biosimulation of Telomeric DNA/RNA: A Biospectroscopic and Photobiological Study. (2016) J Res Development 4: 144.

Pubmed | Crossref | Others

12. Heidari, A. Biochemical and Pharmacodynamical Study of Microporous Molecularly Imprinted Polymer Selective for Vancomycin, Teicoplanin, Oritavancin, Telavancin and Dalbavancin Binding. (2016) Biochem Physiol 5: 146.

Pubmed | Crossref | Others

13. Heidari, A. Anti-Cancer Effect of UV Irradiation at Presence of Cadmium Oxide (CdO) Nanoparticles on DNA of Cancer Cells: A Photodynamic Therapy Study. (2016) Arch Cancer Res 4: 1 .

Pubmed $\mid$ Crossref $\mid$ Others

14. Heidari, A. Biospectroscopic Study on Multi-Component Reactions (MCRs) in Two A-Type and B-Type Conformations of Nucleic Acids to Determine Ligand Binding Modes, Binding Constant and Stability of Nucleic Acids in Cadmium Oxide (CdO) Nanoparticles-Nucleic Acids Complexes as Anti-Cancer Drugs. (2016) Arch Cancer Res 4: 2.

Pubmed $\mid$ Crossref $\mid$ Others
15. Heidari, A. "Simulation of Temperature Distribution of DNA/RNA of Human Cancer Cells Using Time-Dependent Bio-Heat Equation and Nd: YAG Lasers". (2016) Arch Cancer Res 4: 2.

Pubmed | Crossref $\mid$ Others

16. Heidari, A. Quantitative Structure-Activity Relationship (QSAR) Approximation for Cadmium Oxide (CdO) and Rhodium (III) Oxide $\left(\mathrm{Rh}_{2} \mathrm{O}_{3}\right)$ Nanoparticles as Anti-Cancer Drugs for the Catalytic Formation of Proviral DNA from Viral RNA Using Multiple Linear and NonLinear Correlation Approach. (2016) Ann Clin Lab Res 4: 1.

Pubmed | Crossref $\mid$ Others

17. Heidari A. Biomedical Study of Cancer Cells DNA Therapy Using Laser Irradiations at Presence of Intelligent Nanoparticles. (2016) J Biomedical Sci 5: 2

Pubmed | Crossref | Others

18. Heidari, A. Measurement the Amount of Vitamin D2 (Ergocalciferol), Vitamin D3 (Cholecalciferol) and Absorbable Calcium $\left(\mathrm{Ca}^{2+}\right)$, Iron (II) $\left(\mathrm{Fe}^{2+}\right)$, Magnesium $\left(\mathrm{Mg}^{2+}\right)$, Phosphate $\left(\mathrm{PO}^{4}\right)$ and $\mathrm{Zinc}\left(\mathrm{Zn}^{2+}\right)$ in Apricot Using High-Performance Liquid Chromatography (HPLC) and Spectroscopic Techniques. (2016) J Biom Biostat 7: 292.

Pubmed | Crossref | Others

19. Heidari, A. Spectroscopy and Quantum Mechanics of the Helium Dimer $\left(\mathrm{He}^{2+}\right)$, Neon Dimer $\left(\mathrm{Ne}^{2+}\right)$, Argon Dimer $\left(\mathrm{Ar}^{2+}\right)$, Krypton Dimer $\left(\mathrm{Kr}^{2+}\right)$, Xenon Dimer $\left(\mathrm{Xe}^{2+}\right)$, Radon Dimer $\left(\mathrm{Rn}^{2+}\right)$ and Ununoctium Dimer $\left(\mathrm{Uuo}^{2+}\right)$ Molecular Cations. (2016) J Chem Sci 7: 112.

Pubmed $\mid$ Crossref $\mid$ Others

20. Heidari, A. Human Toxicity Photodynamic Therapy Studies on DNA/RNA Complexes as a Promising New Sensitizer for the Treatment of Malignant Tumors Using Bio-Spectroscopic Techniques. (2016) J Drug Metab Toxicol 7: 129.

Pubmed | Crossref | Others

21. Heidari, A. Novel and Stable Modifications of Intelligent Cadmium Oxide (CdO) Nanoparticles as Anti-Cancer Drug in Formation of Nucleic Acids Complexes for Human Cancer Cells' Treatment. (2016) Biochem Pharmacol (Los Angel) 5: 207.

Pubmed | Crossref | Others

22. Heidari, A. A Combined Computational and QM/MM Molecular Dynamics Study on Boron Nitride Nanotubes (BNNTs), Amorphous Boron Nitride Nanotubes (a-BNNTs) and Hexagonal Boron Nitride Nanotubes (h-BNNTs) as Hydrogen Storage. (2016) Struct Chem Crystallogr Commun 2: 1 .

Pubmed $\mid$ Crossref $\mid$ Others

23. Heidari, A. Pharmaceutical and Analytical Chemistry Study of Cadmium Oxide (CdO) Nanoparticles Synthesis Methods and Properties as Anti-Cancer Drug and its Effect on Human Cancer Cells. (2016) Pharm Anal Chem Open Access 2: 113.

Pubmed $\mid$ Crossref $\mid$ Others

24. Heidari, A. A Chemotherapeutic and Biospectroscopic Investigation of the Interaction of Double-Standard DNA/RNA-Binding Molecules with Cadmium Oxide (CdO) and Rhodium (III) Oxide $\left(\mathrm{Rh}_{2} \mathrm{O}_{3}\right)$ Nanoparticles as Anti-Cancer Drugs for Cancer Cells' Treatment. (2016) Chemo Open Access 5: 129.

Pubmed | Crossref $\mid$ Others

25. Heidari, A. Pharmacokinetics and Experimental Therapeutic Study of DNA and Other Biomolecules Using Lasers: Advantages and Applications. (2016) J Pharmacokinet Exp Ther 1: 005.

Pubmed | Crossref | Others

26. Heidari, A. Determination of Ratio and Stability Constant of DNA/ RNA in Human Cancer Cells and Cadmium Oxide (CdO) Nanoparticles Complexes Using Analytical Electrochemical and Spectroscopic Techniques. (2016) Insights Anal Electrochem 2: 1.

Pubmed | Crossref $\mid$ Others

27. Heidari, A. Discriminate between Antibacterial and Non-Antibacterial Drugs Artificial Neutral Networks of a Multilayer Perceptron (MLP) Type Using a Set of Topological Descriptors. (2016) J Heavy Met Toxicity Dis 1: 2 .

Pubmed | Crossref $\mid$ Others 
28. Heidari, A. Combined Theoretical and Computational Study of the Belousov-Zhabotinsky Chaotic Reaction and Curtius Rearrangement for Synthesis of Mechlorethamine, Cisplatin, Streptozotocin, Cyclophosphamide, Melphalan, Busulphan and BCNU as Anti-Cancer Drugs. (2016) Insights Med Phys 1: 2.

Pubmed | Crossref $\mid$ Others

29. Heidari, A. A Translational Biomedical Approach to Structural Arrangement of Amino Acids' Complexes: A Combined Theoretical and Computational Study. (2016) Transl Biomed 7: 2.

Pubmed | Crossref | Others

30. Heidari, A. Ab Initio and Density Functional Theory (DFT) Studies of Dynamic NMR Shielding Tensors and Vibrational Frequencies of DNA/RNA and Cadmium Oxide (CdO) Nanoparticles Complexes in Human Cancer Cells. (2016) J Nanomedine Biotherapeutic Discov 6: 144.

Pubmed | Crossref | Others

31. Heidari, A. Molecular Dynamics and Monte-Carlo Simulations for Replacement Sugars in Insulin Resistance, Obesity, LDL Cholesterol, Triglycerides, Metabolic Syndrome, Type 2 Diabetes and Cardiovascular Disease: A Glycobiological Study. (2016) J Glycobiol 5: 111.

Pubmed | Crossref | Others

32. Heidari, A. Synthesis and Study of 5-(Phenylsulfonyl) Amino.-1, 3, 4-Thiadiazole-2-Sulfonamide as Potential Anti-Pertussis Drug Using Chromatography and Spectroscopy Techniques. (2016) Transl Med (Sunnyvale) 6: 138 .

Pubmed $\mid$ Crossref $\mid$ Others

33. Heidari, A. Nitrogen, Oxygen, Phosphorus and Sulphur Heterocyclic Anti-Cancer Nano Drugs Separation in the Supercritical Fluid of Ozone (O3) Using Soave-Redlich-Kwong (SRK) and Pang-Robinson (PR) Equations. (2016) Electronic J Biol 12: 4.

Pubmed | Crossref $\mid$ Others

34. Heidari, A. An Analytical and Computational Infrared Spectroscopic Review of Vibrational Modes in Nucleic Acids. (2016) Austin J Anal Pharm Chem 3(1): 1058.

Pubmed $\mid$ Crossref $\mid$ Others

35. Heidari, A., Brown, C. Phase, Composition and Morphology Study and Analysis of Os-Pd/HfC Nanocomposites. (2016) Nano Res Appl 2: 1 .

Pubmed $\mid$ Crossref $\mid$ Others

36. Heidari, A., Brown, C. Vibrational Spectroscopic Study of Intensities and Shifts of Symmetric Vibration Modes of Ozone Diluted by Cumene. (2016) International J Adv Chem 4(1): 5-9.

Pubmed | Crossref | Others

37. Heidari, A. Study of the Role of Anti-Cancer Molecules with Different Sizes for Decreasing Corresponding Bulk Tumor Multiple Organs or Tissues. (2016) Arch Can Res 4: 2.

Pubmed $\mid$ Crossref $\mid$ Others

38. Heidari, A. Genomics and Proteomics Studies of Zolpidem, Necopidem, Alpidem, Saripidem, Miroprofen, Zolimidine, Olprinone and Abafungin as Anti-Tumor, Peptide Antibiotics, Antiviral and Central Nervous System (CNS) Drugs. (2016) J Data Mining Genomics \& Proteomics 7: 125.

Pubmed | Crossref | Others

39. Heidari, A. Pharmacogenomics and Pharmacoproteomics Studies of Phosphodiesterase-5 (PDE5) Inhibitors and Paclitaxel Albumin-Stabilized Nanoparticles as Sandwiched Anti-Cancer Nano Drugs between Two DNA/RNA Molecules of Human Cancer Cells. (2016) J Pharmacogenomics Pharmacoproteomics 7: 153.

Pubmed | Crossref | Others

40. Heidari, A. Biotranslational Medical and Biospectroscopic Studies of Cadmium Oxide (CdO) Nanoparticles-DNA/RNA Straight and Cycle Chain Complexes as Potent Anti-Viral, Anti-Tumor and Anti-Microbial Drugs: A Clinical Approach. (2016) Transl Biomed 7: 2.

Pubmed $\mid$ Crossref $\mid$ Others
41.Heidari, A. A Comparative Study on Simultaneous Determination and Separation of Adsorbed Cadmium Oxide (CdO) Nanoparticles on DNA/RNA of Human Cancer Cells Using Biospectroscopic Techniques and Dielectrophoresis (DEP) Method. (2016) Arch Can Res 4: 2.

Pubmed | Crossref $\mid$ Others

42. Heidari, A. Cheminformatics and System Chemistry of Cisplatin, Carboplatin, Nedaplatin, Oxaliplatin, Heptaplatin and Lobaplatin as Anti-Cancer Nano Drugs: A Combined Computational and Experimental Study. (2016) J Inform Data Min 1: 3.

Pubmed | Crossref $\mid$ Others

43. Heidari, A. Linear and Non-Linear Quantitative Structure-AntiCancer-Activity Relationship (QSACAR) Study of Hydrous Ruthenium (IV) Oxide $\left(\mathrm{RuO}_{2}\right)$ Nanoparticles as Non-Nucleoside Reverse Transcriptase Inhibitors (NNRTIs) and Anti-Cancer Nano Drugs. (2016) J Integr Oncol 5: 110.

Pubmed $\mid$ Crossref $\mid$ Others

44. Heidari, A. Synthesis, Characterization and Biospectroscopic Studies of Cadmium Oxide (CdO) Nanoparticles-Nucleic Acids Complexes Absence of Soluble Polymer as a Protective Agent Using Nucleic Acids Condensation and Solution Reduction Method. (2016) J Nanosci Curr Res 1: 101.

Pubmed $\mid$ Crossref $\mid$ Others

45. Heidari, A. Coplanarity and Collinearity of 4'-Dinonyl-2,2'-Bithiazole in One Domain of Bleomycin and Pingyangmycin to be Responsible for Binding of Cadmium Oxide (CdO) Nanoparticles to DNA/ RNA Bidentate Ligands as Anti-Tumor Nano Drug. (2016) Int J Drug Dev \& Res 8: 007-008.

Pubmed | Crossref $\mid$ Others

46. Heidari, A. A Pharmacovigilance Study on Linear and Non-Linear Quantitative Structure (Chromatographic) Retention Relationships (QSRR) Models for the Prediction of Retention Time of Anti-Cancer Nano Drugs under Synchrotron Radiations. (2016) J Pharmacovigil 4: 161.

Pubmed | Crossref | Others

47. Heidari, A. Nanotechnology in Preparation of Semipermeable Polymers. (2016) J Adv Chem Eng 6: 157.

Pubmed $\mid$ Crossref $\mid$ Others

48. Heidari, A. A Gastrointestinal Study on Linear and Non-Linear Quantitative Structure (Chromatographic) Retention Relationships (QSRR) Models for Analysis 5-Aminosalicylates Nano Particles as Digestive System Nano Drugs under Synchrotron Radiations. (2016) J Gastrointest Dig Syst 6: 119.

Pubmed $\mid$ Crossref $\mid$ Others

49. Heidari, A. DNA/RNA Fragmentation and Cytolysis in Human Cancer Cells Treated with Diphthamide Nano Particles Derivatives. (2016) Biomedical Data Mining 5: 102.

Pubmed | Crossref | Others

50. Heidari, A. A Successful Strategy for the Prediction of Solubility in the Construction of Quantitative Structure-Activity Relationship (QSAR) and Quantitative Structure-Property Relationship (QSPR) under Synchrotron Radiations Using Genetic Function Approximation (GFA) Algorithm. (2016) J Mol Biol Biotechnol 1: 1.

Pubmed | Crossref | Others

51. Heidari, A. Computational Study on Molecular Structures of C20, C60, C240, C540, C960, C2160 and C3840 Fullerene Nano Molecules under Synchrotron Radiations Using Fuzzy Logic. (2016) J Material Sci Eng 5: 282.

Pubmed | Crossref | Others

52. Heidari, A. Graph Theoretical Analysis of Zigzag Polyhexamethylene Biguanide, Polyhexamethylene Adipamide, Polyhexamethylene Biguanide Gauze and Polyhexamethylene Biguanide Hydrochloride (PHMB) Boron Nitride Nanotubes (BNNTs), Amorphous Boron Nitride Nanotubes (a-BNNTs) and Hexagonal Boron Nitride Nanotubes (h-BNNTs). (2016) J Appl Computat Math 5: 143.

Pubmed $\mid$ Crossref $\mid$ Others 
53. Heidari, A. The Impact of High Resolution Imaging on Diagnosis. (2016) Int J Clin Med Imaging 3: 1000e101.

Pubmed $\mid$ Crossref $\mid$ Others

54. Heidari, A. A Comparative Study of Conformational Behavior of Isotretinoin (13-Cis Retinoic Acid) and Tretinoin (All-Trans Retinoic Acid (ATRA)) Nano Particles as Anti-Cancer Nano Drugs under Synchrotron Radiations Using Hartree-Fock (HF) and Density Functional Theory (DFT) Methods. (2016) Insights in Biomed 1: 2.

Pubmed | Crossref | Others

55. Heidari, A. Advances in Logic, Operations and Computational Mathematics. (2016) J Appl Computat Math 5: 5.

Pubmed | Crossref | Others

56. Heidari, A. Mathematical Equations in Predicting Physical Behavior. (2016) J Appl Computat Math 5: 5.

Pubmed | Crossref | Others

57. Heidari, A. Chemotherapy a Last Resort for Cancer Treatment. (2016) Chemo Open Access 5: 4.

Pubmed $\mid$ Crossref $\mid$ Others

58. Heidari, A. Separation and Pre-Concentration of Metal CationsDNA/RNA Chelates Using Molecular Beam Mass Spectrometry with Tunable Vacuum Ultraviolet (VUV) Synchrotron Radiation and Various Analytical Methods. (2016) Mass Spectrom Purif Tech 2: 101.

Pubmed $\mid$ Crossref $\mid$ Others

59. Heidari, A. Yoctosecond Quantitative Structure-Activity Relationship (QSAR) and Quantitative Structure-Property Relationship (QSPR) under Synchrotron Radiations Studies for Prediction of Solubility of Anti-Cancer Nano Drugs in Aqueous Solutions Using Genetic Function Approximation (GFA) Algorithm. (2016) Insight Pharm Res 1: 1. Pubmed $\mid$ Crossref $\mid$ Others

60. Heidari, A. Cancer Risk Prediction and Assessment in Human Cells under Synchrotron Radiations Using Quantitative Structure Activity Relationship (QSAR) and Quantitative Structure Properties Relationship (QSPR) Studies. (2016) Int J Clin Med Imaging 3: 516.

Pubmed $\mid$ Crossref $\mid$ Others

61. Heidari, A. A Novel Approach to Biology, Electronic. (2016) J Biol 12: 4.

Pubmed $\mid$ Crossref $\mid$ Others

62. Heidari, A. Innovative Biomedical Equipment's for Diagnosis and Treatment. (2016) J Bioengineer \& Biomedical Sci 6: 2.

Pubmed | Crossref | Others

63. Heidari, A. Integrating Precision Cancer Medicine into Healthcare, Medicare Reimbursement Changes and the Practice of Oncology. Trends in Oncology Medicine and Practices. (2016) J Oncol Med \& Pract 1: 2 .

Pubmed $\mid$ Crossref $\mid$ Others

64. Heidari, A. Promoting Convergence in Biomedical and Biomaterials Sciences and Silk Proteins for Biomedical and Biomaterials Applications: An Introduction to Materials in Medicine and Bioengineering Perspectives. (2016) J Bioengineer \& Biomedical Sci 6: 3.

Pubmed $\mid$ Crossref $\mid$ Others
65. Heidari, A. X-Ray Fluorescence and X-Ray Diffraction Analysis on Discrete Element Modeling of Nano Powder Metallurgy Processes in Optimal Container Design. (2017) J Powder Metall Min 6: 1.

Pubmed | Crossref | Others

66. Heidari, A. Biomolecular Spectroscopy and Dynamics of NanoSized Molecules and Clusters as Cross-Linking-Induced Anti-Cancer and Immune-Oncology Nano Drugs Delivery in DNA/RNA of Human Cancer Cells' Membranes under Synchrotron Radiations: A PayloadBased Perspective. (2017) Arch Chem Res 1: 2.

Pubmed | Crossref | Others

67. Heidari, A. Deficiencies in Repair of Double-Standard DNA/RNABinding Molecules Identified in Many Types of Solid and Liquid Tumors Oncology in Human Body for Advancing Cancer Immunotherapy Using Computer Simulations and Data Analysis. (2017) J Appl Bioinforma Comput Biol 6: 1.

Pubmed | Crossref | Others

68. Heidari, A. Electronic Coupling among the Five Nanomolecules Shuts Down Quantum Tunneling in the Presence and Absence of an Applied Magnetic Field for Indication of the Dimer or other Provide Different Influences on the Magnetic Behavior of Single Molecular Magnets (SMMs) as Qubits for Quantum Computing. (2017) Glob J Res Rev 4: 2.

Pubmed $\mid$ Crossref $\mid$ Others

69. Heidari, A. Polymorphism in Nano-Sized Graphene Ligand-Induced Transformation of $\mathrm{Au} 38-\mathrm{xAgx} / \mathrm{xCux}(\mathrm{SPh}-\mathrm{tBu}) 24$ to Au36$\mathrm{xAgx} / \mathrm{xCux}(\mathrm{SPh}-\mathrm{tBu}) 24(\mathrm{x}=1-12)$ Nanomolecules for Synthesis of Au144-xAgx/xCux(SR)60, (SC4)60, (SC6)60, (SC12)60, (PET)60, (p-MBA)60, (F)60, (Cl)60, (Br)60, (I)60, (At)60, (Uus)60 and (SC6H13)60. Nano Clusters as Anti-Cancer Nano Drugs. (2017) J Nanomater Mol Nanotechnol 6: 3

Pubmed | Crossref | Others

70. Heidari, A. Biomedical Resource Oncology and Data Mining to Enable Resource Discovery in Medical, Medicinal, Clinical, Pharmaceutical, Chemical and Translational Research and Their Applications in Cancer Research. (2017) Int J Biomed Data Min 6: 103.

Pubmed | Crossref | Others

71. Heidari, A. Study of Synthesis, Pharmacokinetics, Pharmacodynamics, Dosing, Stability, Safety and Efficacy of Olympiadane Nanomolecules as Agent for Cancer Enzymotherapy, Immunotherapy, Chemotherapy, Radiotherapy, Hormone Therapy and Targeted Therapy under Synchrotorn Radiation. (2017) J Dev Drugs 6: 154.

Pubmed | Crossref | Others

72. Heidari, A. A Novel Approach to Future Horizon of Top Seven Biomedical Research Topics to Watch in 2017: Alzheimer's, Ebola, Hypersomnia, Human Immunodeficiency Virus (HIV), Tuberculosis (TB), Microbiome/Antibiotic Resistance and Endovascular Stroke. (2017) J Bioengineer \& Biomedical Sci 7: 127.

Pubmed | Crossref $\mid$ Others

73. Heidari, A. Opinion on Computational Fluid Dynamics (CFD)

Technique. (2017) Fluid Mech Open Acc 4: 157.

Pubmed | Crossref | Others
Ommega Online Publishers

Journal Title: Journal of Pharmacy \& Pharmaceutics

Journal Short Name: J Pharm Pharmaceutics
Journal ISSN: 2377-1313

E-mail: pharmacoinformatics@ommegaonline.com

Website: www.ommegaonline.org 